\title{
New forage crop introductions for the semi-arid highland areas of Kenya as a means to increase beef production
}

H. van Arkel

UNDP/FAO Kenya Beef Industry Development Project, P.O. Box 1275, Nakuru, Kenya

Accepted: 13 April 1977

Key words: forage crops, silage, beef, feedlots, zebu, sorghum, maize, sunflower, bulrush millet, cold tolerance, drought resistance

\section{Summary}

A UNDP/FAO Development Project has initiated and aided the establishment of a commercial beef cattle finishing sector in the Kenya agriculture. The feeding systems developed utilize surplus cattle from rural areas which are fed on rations based on maize silage. The project has now initiated a search for forage crops suitable for cultivation under highland conditions, but more drought-resistant than the presently used maize. It appeared that new introductions of cold-tolerant sorghums from the high-altitude areas of Uganda and Ethiopia produced consistently good yields which were comparable to, or better than, maize.

Some of the high altitude sorghums were completely free from diseases which are typically encountered when 'lowland' sorghums are grown above $1600 \mathrm{~m}$ in Kenya. In contrast with maize and sunflower, the new sorghum introductions were highly resistant to lodging. Correlation analysis showed that the unwanted tallness of crops is highly associated with the yield of maize and sunflower, whereas with cold-tolerant sorghums there is scope for selection or breeding of high-yielding material which is shorter. The single highest-yielding entry for cold-tolerant sorghum, sunflower and maize produced $30.5,29.5$ and 26.6 tons DM ha ${ }^{-1}$, respectively.

\section{Introduction}

Agricultural development activities in developing countries, directed towards increasing productivity are usually concerned either with the introduction of distinct agrotechnical innovations or their individual merits. There is, however, a growing recognition that development programmes linking several sectors of a country's economy have an important role to play in rural development. (Taylor, 1974; Anon., 1973). The Kenya Beef Industry Development Project is an example of such an 
'Integrated Rural Development Project', although it is unusual in that it is using large-scale farming methods to introduce new technology, while relying on market mechanisms to spread the resulting benefits. Because of its success, the project has created its own research needs which led directly to the necessity for an identification of additional forage crops.

The introduction in 1969 of intensive systems for beef cattle finishing to induce a stratification in the beef cattle industry, was a basic innovation in the Kenya agricultural economy aimed at increasing the productivity of the large numbers of indigenous pastoral Zebu cattle (Bos indicus). This feedlot system (Creek, 1971) proved to be successful on a technical level and its economic attraction was confirmed by an extensive commercial interest.

Because of the limited land area available for intensive feeding systems the project was requested to develop alternative forages suited to land of lower agricultural potential. This paper briefly describes the feedlot system against the background of traditional beef cattle raising systems. The results of a species introduction and screening trial to find new forages suitable for silage production are discussed.

\section{Agricultural potential, cattle distribution and beef supply}

A large proportion of the land surface of Kenya receives insufficient rainfall to sustain crop production. A belt along the coast and an area around Lake Victoria has a higher precipitation. Areas with a higher elevation usually receive more rainfall as well.

Altitude effects agricultural potential in two ways, via rainfall and temperature. It has been calculated in Kenya that the mean diurnal temperature decreases by $6.5^{\circ} \mathrm{C}$ for every $1000 \mathrm{~m}$ increase in height above sea level (Anon., 1970a). Therefore at the higher altitudes where precipitation is relatively plentiful, moisture availability to the plant is further increased by reduced evaporation due to lower temperatures. However, lower temperatures reduce growth rates of some crops and completely preclude the cultivation of others such as sugar-cane which require warm growing conditions.

Various attempts have been made during the past twenty-five years to classify the different zones of climatic conditions according to their agricultural potential. Swynnerton (1955) recognizes two classes, high and low potential, and Brown (1963) adds a class of medium ecological potential. For the purposes of this paper Brown's classification, slightly refined, will suffice.

The uneven distribution of rainfall is also reflected in the human population and cattle distribution; in the drier areas people keep more cattle. The broad boundaries of the agricultural potential classes can be readjusted for a discussion of the potential for supply of beef: (Table 1).

1. The area with more than $750 \mathrm{~mm}$ annual rainfall. Cattle are kept mainly for dairying, either for subsistence or to supply the market. Male calves are usually killed at birth as they are uneconomic to rear.

2. The area with between 500 and $750 \mathrm{~mm}$ annual rainfall. Here commercial ranches are mainly found. The cattle breeds used are either 'Improved Boran', a 


\section{NEW FORAGE CROPS FOR INCREASING BEEF PRODUCTION IN KENYA}

Table 1. Beef supply potential related to land classification.

\begin{tabular}{|c|c|c|c|}
\hline $\begin{array}{l}\text { Agricultural potential } \\
\text { (Brown, 1963) }\end{array}$ & $\begin{array}{l}\text { Number of ha } \\
(\% \text { of land area) }\end{array}$ & Maize production potential & $\begin{array}{l}\text { Beef } \\
\text { supply } \\
\text { class }\end{array}$ \\
\hline $\begin{array}{l}\text { 'High potential area' with } \\
\text { more than } 875 \mathrm{~mm} \text { rainfall p.a. }\end{array}$ & $\begin{array}{l}6.69 \times 10^{6} \mathrm{ha} \\
(11.89 \%)\end{array}$ & $\begin{array}{l}\text { a good maize grain crop production } \\
\text { is possible every year if altitude is } \\
\text { less than } 2300 \mathrm{~m}\end{array}$ & 1 \\
\hline \multirow[t]{2}{*}{$\begin{array}{l}\text { 'Medium potential area' with } \\
625-875 \mathrm{~mm} \text { rainfall p.a. }\end{array}$} & $\begin{array}{l}3.13 \times 10^{6} \text { ha } \\
(5.57 \%)\end{array}$ & $\begin{array}{l}750 \text { to } 875 \mathrm{~mm} \text { : a good to average } \\
\text { grain crop production is possible } \\
\text { every year }\end{array}$ & 1 \\
\hline & & $\begin{array}{l}625 \text { to } 750 \mathrm{~mm} \text { : an average to low } \\
\text { maize grain crop production is } \\
\text { possible every year; } \\
\text { excellent rangelands }\end{array}$ & 2 \\
\hline \multirow[t]{2}{*}{$\begin{array}{l}\text { 'Low potential area' semi-arid } \\
\text { to arid lands with rainfall less } \\
\text { than } 625 \mathrm{~mm} \text { p.a. }\end{array}$} & $\begin{array}{l}41.74 \times 10^{6} \text { ha } \\
(74.22 \%)\end{array}$ & $\begin{array}{l}500 \text { to } 625 \mathrm{~mm} \text { : maize grain crop } \\
\text { failure in three to four years out of } \\
\text { five; good to average rangelands }\end{array}$ & 2 \\
\hline & & $\begin{array}{l}\text { less than } 500 \mathrm{~mm} \text { : maize production } \\
\text { impossible; poor rangelands; pastoral } \\
\text { cattle husbandry is the only way of } \\
\text { agricultural production }\end{array}$ & 3 \\
\hline Remaining area & $\begin{array}{l}4.69 \times 10^{6} \text { ha } \\
(8.34 \%)\end{array}$ & & \\
\hline Total area & $\begin{array}{l}56.24 \times 10^{6} \text { ha } \\
(100 \%)\end{array}$ & & \\
\hline
\end{tabular}

selection from indigenous Zebu, or crosses between these Borans and European breeds. These ranches have traditionally been self-contained units, where the breeding, growing out and finishing of beef cattle are combined in one enterprise.

3. The low potential area with less than $500 \mathrm{~mm}$ rainfall. Livestock raising is still in its most traditional, semi-nomadic form and there is little production for a market. Instead it is subsistence farming emphasizing female cattle as the most valuable assets on account of their milk production. Male cattle are kept as reserve assets for sale when cash is required. The breed of cattle here is pure Zebu.

In spatial terms $45 \%$ of the national cattle herd is kept in the arid and semi-arid low potential areas. It has been recognized in the national plans that cattle must play an integral role in the agricultural development of the large dry areas of Kenya (Anon., 1973). The need for, and the scope of, livestock development programmes is implied by the low annual off-take of approximately $13 \%$, and from the large proportion of low-grade, light weight carcasses which are processed by the abattoirs (Daly, 1974; Anon., 1974, 1975). In 1968 the UNDP/FAO/Kenya Beef Industry Development Project was thus initiated to study the possibilities of 
increasing beef production in Kenya. It was clear from the outset of this project that native Zebu cattle from the low potential area had to play an important role in its investigations. The project was directed to promote stratification of production, separating the breeding, growing out and finishing phases of beef production in different areas. The feedlot finishing phase was given prime attention as a tool to induce the stratification of the whole industry.

\section{The feedlot system for intensive finishing}

The American feedlot system was modified by the project for introduction into Kenya, and it is essentially a short period of intensive feeding to ensure that cattle are brought to their optimal condition prior to slaughter. The project has demonstrated two significant findings: it has proven that pastoral indigenous Zebu cattle, when coming from the range, can respond very well to intensive feeding (Creek, 1971), and it has shown that agro-industrial by-products, e.g. molasses and pyrethrum residue, can successfully be included in the rations (Creek, 1973).

Local Zebu cattle respond well to high levels of roughage in the ration, thus reducing the necessary amounts of the more expensive high-energy components in the ration to a very modest amount (Table 2).

A survey of several feedlot farms showed an average yield of 10.5 tons of DM out of the silage pit per ha of maize forage. This implies (Table 2) that on a feedlot finishing farm 46 Zebus or 57 cross-breed cattle can be fed from 1.0 ha of maize, provided the necessary non-forage ration components are available. 46 Zebu's deliver a carcass weight increase of 2.4 tons while for 57 cross-breed cattle the carcass weight gain is 4.7 tons. Because feeder cattle usually have a fully developed skeleton before entering the feedlot, the above figures represent an almost complete increase in edible meat.

Table 2. Expected performance of two types of cattle during feedlot finishing (Creek and van Arkel, unpublished).

\begin{tabular}{lcc}
\hline & Zebu & Cross-breed \\
& High roughage $(66 \%)$ & Low roughage (33\%) \\
Initial live-weight $(\mathrm{kg})$ & 260 & 350 \\
Initial dressing percentage & 47.5 & 48.0 \\
Days on feed & 81 & 95 \\
Final live-weight $(\mathrm{kg})$ & 340 & 478 \\
Final dressing percentage & 51.5 & 52.3 \\
Daily live-weight gain $(\mathrm{kg})$ & 1.0 & 1.3 \\
Total live-weight gain $(\mathrm{kg})$ & 80 & 128 \\
Carcass weight increase $(\mathrm{kg})$ & 52 & 82 \\
Conversion ratio & $7: 1$ & $7: 1$ \\
Feed DM used (kg) & & \\
$\quad$ forage (maize silage) & 228 & 183 \\
$\quad$ non-forage (agro-industrial by-products) & 152 & 122 \\
$\quad$ roughage & 190 & 611 \\
\hline
\end{tabular}


The feedlot system increases the amount of beef reaching the slaughterhouse in two ways. It increases the beef off-take by producing heavier carcasses by virtue of the additional finishing they receive. Also it offers attractive prices for young unfinished stock which are well above their current slaughter value. The sale of this young stock to the feedlot releases grazing for breeding females, hence offering a chance of increasing their productivity. Thus far, feedlot rations have mainly been based on maize silage as a source of forage. It is, however, quite clear that in areas where maize can be cultivated there is a social pressure to develop smallholder systems of farming with the main product being maize grain for human consumption. Consequently the need was foreseen to develop alternative feeding systems to maize silage. For this reason studies on the use of high levels of molasses (Creek et al., 1974) and of fresh sugar-cane (Creek et al., 1976) were undertaken. Simultaneously, the search was commenced for a suitable forage crop for cattle feeding operations which can be grown in those parts of the high-altitude (HA) areas, i.e. $>1600 \mathrm{~m}$, where arable agricultural potential is less favourable and where the human population is much lower. Such crops must therefore be more drought-resistant than maize, while they must also have the ability to withstand the relatively low temperatures prevailing in the highlands. The restriction on altitude was made because this area has a well developed infrastructure and is free from foot-and-mouth disease.

\section{Crop literature review and entry selection}

Few studies with silage crops have been conducted under the special climatic conditions of Kenya's highlands where solar radiation and photoperiod are tropical, and temperatures are temperate and rainfall varies from semi-arid to medium-wet. A brief literature survey for the potentially suitable species follows, together with the origin of cultivars to be tested in three introduction and screening trials.

\section{Sorghum (Sorghum bicolor (L) Moench)}

It is generally accepted that sorghums are more drought-resistant than maize. Martin (1930) showed that sorghums have a more xeromorphic structure than maize, the number of stomata per $\mathrm{cm}^{2}$ of leaf area is higher, while the individual size is smaller. The leaf stalk surface is covered with a waxy cutinized epidermis, also osmotic concentration of leaf juice is higher and evaporation during periods of moisture stress is lower. Glover (1959) proved that sorghum, after a period of moisture stress, re-commences photosynthesis immediately, whereas maize, although it regains turgidity when the water supply is restored, does not recover its normal photosynthetic behaviour. Despite its drought resistance sorghum is seldom grown in the dry areas of the Kenya Highlands nowadays. Various attempts to introduce grain sorghums here have failed completely in the past, which is - most likely - due to the fact that the germplasm used was not adapted to the relatively low air temperatures.

Quinby et al. (1958) states that minimum temperature for germination of sorghum seed is 7 to $10^{\circ} \mathrm{C}$ and that for subsequent growth is about $15^{\circ} \mathrm{C}$. They also report that the optimum mean temperature for the growth of sorghum is about $27^{\circ} \mathrm{C}$. 
Ross \& Webster (1960) in the USA recommended that sorghum should not be planted where soil temperatures are below $21^{\circ} \mathrm{C}$.

Another limiting factor for sorghum cultivation in the highlands, where low temperatures are coupled with seasonally heavy rainfall, is that honeydew disease (Sphacelia sorghi (McRae)) can be serious. This fungus invades the ovary when pollination is delayed due to cold conditions. Fertilization does not take place and the disease is often followed by a black fruiting fungus (Cerebellum spp.)

Clearly, the above-mentioned problems have contributed to the lack of popularity of sorghum in the Kenya Highlands. Therefore, at the start of the programme, a selection was made from a series of typical high-altitude (HA) sorghums which might be adapted to the prevailing climatic conditions. A great number of sorghums naturally occurring in the high-altitude areas of Ethiopia and Uganda were collected during the 1960's by the East African Agricultural and Forestry Research Organization (EAAFRO) at Serere in Uganda. From this collection the author selected, on a visual basis, a number of lines, which are reported under an ' $E$ ' or a 'Hirna' number.

In addition a small selection of 'lowland' sorghum cultivars and hybrids was made by the US Department of Agriculture, by various commercial American seed companies and by Israelian and Kenyan sources for inclusion in the trial.

Some other sorghums which are sometimes cultivated in Kenya highlands (Boonman, 1969) such as Columbus grass (Sorghum almum), velvet sorghum (S. halepense $\times S$. bicolor), two sorghum $\times$ Sudan grass hybrids $(S$. bicolor $\times S$. sudanense (Piper) Stapf) and two Sudan grass cultivars ( $S$. sudanense) were also entered in the trial. This group of sorghums is reported under 'Miscellaneous sorghums'.

\section{Sunflower (Helianthus annuus (L))}

Sunflower is widely cultivated for seed, but its productivity and quality as a cattle feed has also been tested under widely differing conditions. Cotte (1957) in France, Bengtsson (1958) in Sweden, Sivokonev (1959) in Russia, Warren Wilson (1966) in Australia, and Henning (1949) in the Republic of South Africa, showed the relatively high drought resistance of sunflower. Several reports indicate that under marginal conditions sunflower may outyield maize in terms of DM ha ${ }^{-1}$ (Putt, 1963 (Canada); Henning, 1949 (South Africa); Hagsand, 1956 (Sweden); Schuster, 1954 (Germany)). Little experience of sunflower for silage is available on the continent of Africa. Henning (1949) in South Africa values the crop highly while Miller et al. (1963) in Nigeria states that, due to the low digestability of the various plant components, no further research with sunflower is warranted. Eijnatten (1971) in Kenya recorded a production of approximately 28 tons $\mathrm{DM} \mathrm{ha}{ }^{-1}$ and, in a later study (Eijnatten, 1973), reasonably good proximate analysis figures for sunflower are shown. A number of locally available sunflowers, some locally adapted and some imported cultivars, were included in the trial.

\section{Bulrush millet (Pennisetum typhoides (Burm) Stapf \& C. E. Hubb)}

This species is known to be remarkably drought-resistant. This is partly on account of its ability to start heading extremely soon when moisture conditions become 
adverse. The term 'drought-escaping' is therefore often used. The composites used in this study were all selected from EAAFRO Uganda. Apart from their drought resistance they have been included for their quick development and their ability to produce regrowth when rainfall is adequate. The species is usually grown for grain production.

\section{Grasses}

Little experience with the agronomy of grass as a forage was available in Kenya at the start of the project, whereas maize agronomy was well developed. The recurrent costs of ploughing and planting involved in the cultivation of annual forage crops make up $32-45 \%$ of the total growing costs. (Anon., 1970b). This certainly makes perennial grasses economically attractive if they can compete in productivity with maize. Rhodes grass (Chloris gayana Kunth cv. Mbarara), and Bana grass (Pennisetum purpureum Schumach.), a newly introduced selection out of Napier grass, were used as test material in the trials.

\section{Maize (Zea mays (L.)}

The four maize cultivars were included in the trials as the controls. ' $H$ 613' and 'H 512' are the most widely used Kenya hybrids, particularly suited to the more productive soils. 'Katumani' is a Kenya composite, selected for drier, semi-arid conditions. 'Local yellow' is a Kenyan adapted selection which is locally said to be able to outyield the hybrids if growing conditions are drier.

\section{Materials and methods}

The trial was planted at three different locations:

Lanet 1. Elevation $1920 \mathrm{~m}$; has a deep sandy loam soil with excellent waterholding capacity, total rainfall during the growing season (March-November) of the year of experimentation (1974) was $810 \mathrm{~mm}$. The trial site is situated approximately $35 \mathrm{~km}$ south of the equator.

Lanet $2.5 \mathrm{~km}$ to the south with an elevation of $1860 \mathrm{~m}$; has a soil of recent volcanic origin with a very shallow topsoil, overlaying ash, pumice and lava material. The waterholding capacity of the soil is very limited and total rainfall for the season was $720 \mathrm{~mm}$.

Naivasha. Elevation $1850 \mathrm{~m}$, approximately $77 \mathrm{~km}$ south of the equator; shows a soil of recent geological origin composed of lake deposits with a clearly developed morphology. The soil is deep, well drained, and has an excellent waterholding capacity. Sowing was delayed for five weeks and this trial was laid down as one completely randomized design. On sowing $70 \mathrm{~mm}$ irrigation was given. The rainfall during the growing season was $420 \mathrm{~mm}$.

A total of 72 different entries were chosen and sown at the beginning of the main growing season at the end of March in a randomized block experiment. Each plot was sown to three rows, $70 \mathrm{~cm}$ apart, $5.0 \mathrm{~m}$ long, except for Rhodes grass which was broadcast overall.

Harvests were taken at the optimal harvesting stage for each crop as specified in 
the literature. This was determined as follows:

- maize, sorghum and bulrush millet at physiological maturity, i.e. at the harddough stage of the grain;

- haygrazer, velvet sorghum, Sudan grass and Columbus grass at $50 \%$ flowering;

- sunflower when $50 \%$ of the florets of $50 \%$ of the heads could be removed by gentle rubbing; this occurs approximately two weeks after the onset of flowering;

- Rhodes grass at the onset of heading;

- Bana grass, when the crop reached a height of $150 \mathrm{~cm}$.

At the predetermined harvesting stage for each plot, one row $4.0 \mathrm{~m}$ long (leaving $0.5 \mathrm{~m}$ at each end of the row), was cut and taken to the laboratory for further plant component analysis. The harvested plants were counted, tiller numbers recorded, individual stem lengths measured and the plants dissected into leaf, stem, grain and, where applicable, petiole (sunflower), husk and empty cob (maize). Dry matter percentage of each component was determined by exposing a subsample for 24 to 48 hours to $90^{\circ} \mathrm{C}$ in a large drying oven.

\section{Results}

The performance data of fifteen entries is shown in Table 3. Each group of crops is represented by one or more of those entries which gave, on the average, the highest $\mathrm{DM}$ or grain yields. The mean DM yield was $17.7,13.3$ and 20.2 tons $^{\text {ha }^{-1}}$ for Lanet 1, Lanet 2 and Naivasha, respectively. It is striking that the mean DM yield at Naivasha was the highest one $(\mathrm{P}<0.05)$ although the rainfall there was lower than at the other two sites. This higher mean DM yield went in conjunction with the longest mean growing period.

Although maize, the control, did not reach a top yield anywhere, the yields obtained were good and comparable to those reported by Sheldrick (1974) in the Trans-Nzoia typical maize growing area. The relatively high maize yields set a high standard for the other groups. These maize DM figures obtained here are considerably higher than those commonly recorded in large-scale maize farming in the area. Lodging in maize was observed in all three trials.

The lowland sorghums were all heavily affected by one or more foliage and head fungus diseases, such as leaf blight (Helminthosporium turcicum (Pass.)), bacteriai stripe (Pseudomonas andropogonis (E.F.Sm.) Stapp.), antracnose (Colletotrichum graminicolum (Ces.) C. W. Wils), rust (Puccinia purpurea Cke.), and honeydew disease (Sphacelia sorghi).

Several of the sorghums of HA origin appeared among the top yielding entries at each trial site, although none of those sorghums outproduced maize consistently. The DM yield of the entries in the other groups was highly variable with trial location (sunflower) or consistently lower than maize (lowland sorghums, miscellaneous sorghums, grasses and bulrush millet).

\section{Discussion}

Suitability for silage making

To the feedlot farmer the stock-piling of feed supplies, which eliminates seasonality 


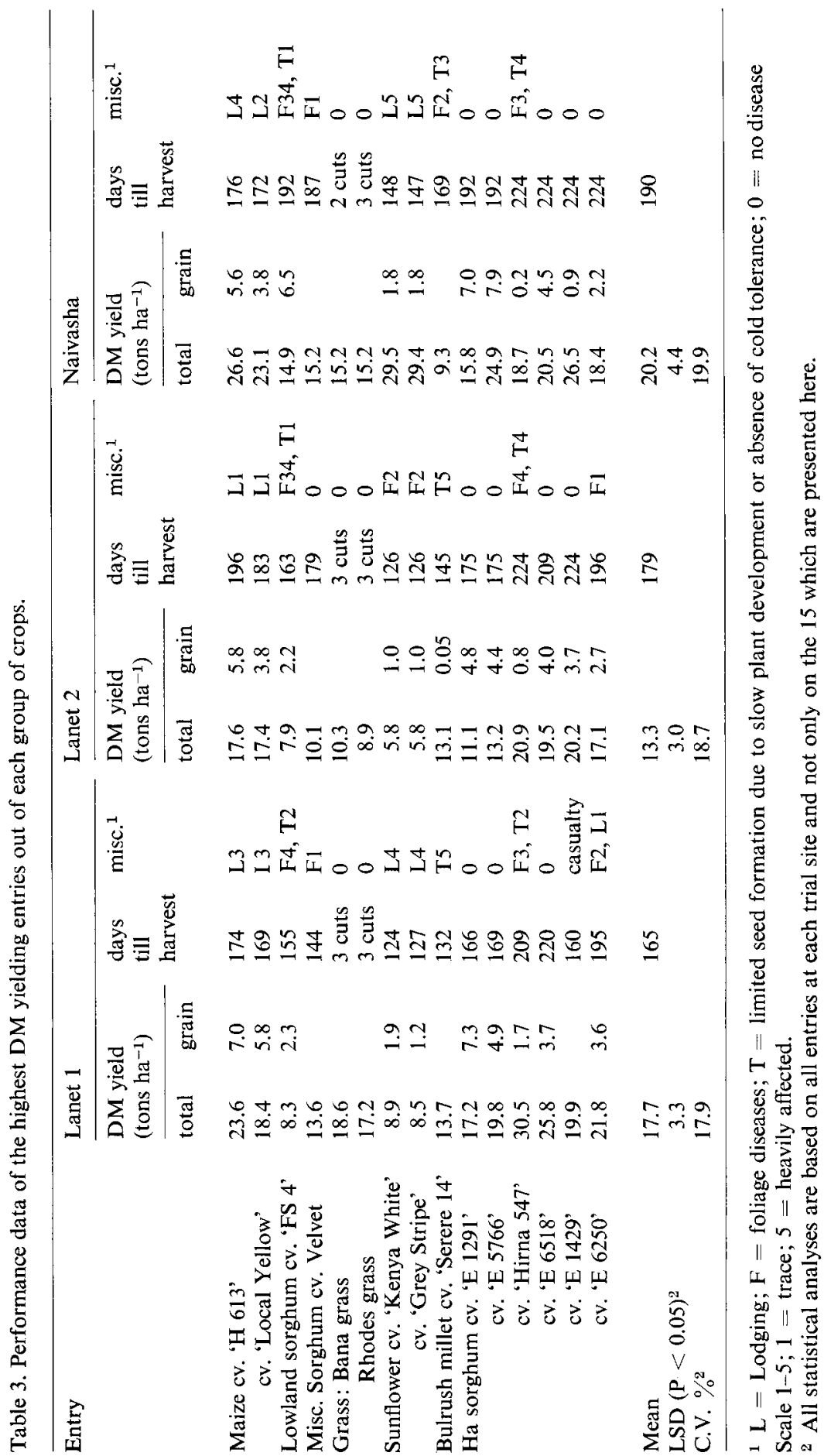

Neth. J. agric. Sci. 25 (1977) 
in beef production, is central to the concept of feedlot finishing. Silage making is the conservation technique of choice, and the crops studied were chosen with this in mind. However, sunflower, and Rhodes grass and Bana grass with average DM figures of $18.9 \%, 22.0 \%$ and $17.5 \%$, respectively, are too wet for easy silage making, although it is possible by using a period of wilting prior to ensiling. But as well as complicating the harvest, it also makes it difficult to obtain silage of uniform quality and DM \%. The need for grasses to be cut several times in one year also reduces the chances of obtaining feed of even quality.

\section{Suitability for mechanical harvesting}

Mechanical forage harvesting is essential for silage production and the actual forage yields obtained are, therefore, a function of crop productivity and harvesting losses. Field experience shows that the latter is closely correlated with lodging. The heavy lodging in maize and sunflower (Table 3 ) is therefore a distinct disadvantage, and the lodging-resistant HA sorghums compare favourably since they can be mechanically harvested with little loss. Work is in progress to study the harvesting losses resulting from lodging in more detail, and loss figures of $30 \%$ for lodged maize have been measured whereas sorghum losses generally remain under $5 \%$.

\section{Performance by trial site and by group}

The highest average DM yield at Naivasha, where rainfall (+ irrigation) was only $490 \mathrm{~mm}$, is probably associated with the superior water-holding capacity of the soil at this trial site, which ensured a high utilization of the precipitation. Wilting was observed only very rarely whereas this was a common phenomenon at the Lanet 2 site where rainfall was more abundant, but the soil very shallow, and the average yield much lower. Therefore Lanet 2 seems to be the best site of all 3 to represent the semi-arid highlands. Indeed it is only here where three HA sorghum cultivars (cvs) outyielded the two best maize cvs by an average $15 \%$. The better moisture availability to the plant at Naivasha as compared with Lanet 2 is also confirmed by the 24 days longer period needed by bulrush millet $\mathrm{cv}$. Serere 14 to reach the harddough stage (Table 3), because days from planting till heading in bulrush millet is known to be negatively correlated with moisture availability.

The low DM yields which were recorded for the lowland sorghums are partly due to the diseases which invaded the crops in the later stages of growth and partly due to the slow growth rates which were observed immediately after emergence. The latter is probably related to the relatively low air temperatures, and this seems to explain previous failures to introduce lowland sorghums in the highlands. Mean daily air temperatures during the growing period for Lanet 1, Lanet 2 and Naivasha were $18.1,18.3$ and $19.5^{\circ} \mathrm{C}$, respectively, which are all well below the reported optimum for sorghum. The American hybrid 'FS 4', which gave the best yield performance in this group, has apparently responded favourably to the increased temperature at Naivasha. The grain yield obtained here ranked No 3 which was significantly better than maize cv. ' $\mathrm{H}$ 613' $(\mathrm{P}<0.05)$. The presence of severe mould on the grain rendered the produce useless however.

The miscellaneous sorghums, containing cultivars which have found a limited 
place in the agriculture of the Kenya highlands as grazing forages, failed to attain a yield level to qualify for the highest ranks. Since their success was under regimes of frequent defoliation, it is hardly surprising that they performed poorly as a long season crop with a single harvest date. In this group velvet sorghum scored highest, which agrees well with earlier work on these sorghums (Boonman, 1969).

The grasses proved unable to rank consistently among the highest producing entries, on account of the potential DM production which was lost during the relatively long-lasting establishment phase. At the Lanet 1 trial site, where rainfall during the first month after sowing was higher than at the other two sites, the grasses established much faster and were able to rank 10th and 13th for Bana and Rhodes grass, respectively. It is clear, however, that no full evaluation of any grass can be given if productivity during the establishment year only is taken into account.

The sunflowers demonstrated the largest interaction between trial site and crops. Some sunflower entries at Naivasha qualify for the very highest DM yield level reached in a relatively short period of time, bringing the growth rate at $199 \mathrm{~kg}$ DM day-1 ${ }^{-1} a^{-1}$. In contrast, at the Lanet 2 trial site the two best cultivars 'Grey Stripe' and 'Kenya White', only reached a mean growth rate of $46 \mathrm{~kg} \mathrm{DM}$ day-1 $\mathrm{ha}^{-1}$. However, it should be noted that the high yield levels were associated with a severe lodging problem. It seems that sunflower is most sensitive to soil depth and that its reported drought resistance is mainly due to an extensive root system rather than due to xeromorphic characteristics. If physical soil properties prohibit the development of such an extensive root system sunflower becomes a vulnerable crop if rainfall is erratic. This is confirmed by Warren Wilson (1966) who studied sunflower under arid conditions in Australia.

Bulrush millet is essentially not a cold-tolerant species, and this was reflected in the almost complete absence of seed formation at all three trial sites. Nevertheless, at Lanet 2, where growing conditions were poorest, the composite 'Serere 14' yielded 13.1 DM tons ha-1 in 145 days. Its growth rate of $90 \mathrm{~kg} \mathrm{DM}$ day-1 ha $^{-1}$ compares well with the growth rate of the highest-yielding entry 'Hirna 547', i.e. $93 \mathrm{~kg} \mathrm{DM}$ day $^{-1} \mathrm{ha}^{-1}$. The growth rate only has a limited value in the interpretation of our trial data since the available growing season was only partially used as none of the entries produced any appreciable regrowth.

The high DM yield of some of the HA sorghums is partly explained by the long growing period required to reach the hard-dough stage (Table 3 ). Within the group of HA sorghums there is a large variability in grain yield. ' $E 1291$ ' and to a lesser extent ' $E$ 5766' produced consistently the highest grain yield at a relatively lower total DM level. It seems therefore appropriate to classify them as grain types, whereas the other cultivars displayed a more forage-type performance with higher DM yields and lower grain yields. Within the latter sub-group grain formation is almost absent in some entries. This was caused by a slow plant development whereby plant heading took place too late in the season to allow successful grain formation.

'E 1291', 'E 5766', 'E 6518' and 'E 1429' were completely free from lodging or any other serious 'set-back'. A small infection of bacterial stripe was recorded in all four cultivars, but this disease is reported to have little effect on crop productivity 
(Edmunds et al., 1970). All four lines were also infected, though very slightly only, with rust, which invaded the older leaves in the later stages of growth. Rust inoculum was also present during the early stages of growth (some lowland sorghums were heavily affected in that stage), and this demonstrates some form of resistance of the four HA lines. Horizontal resistance is not present however and the lines under discussion must be kept under close observation since new, potentially dangerous, rust races may develop.

It appears from the yield figures that the more xeromorphic character of the HA sorghums did not result in a consistently higher DM yield than maize. Three possible explanations offer themselves. The infection with foliage diseases may have affected the production of certain HA sorghum lines to an unpredictable and variable degree. This could explain the interaction between trial site and yield of 'Hirna 547'. The maize entries used in this study are lines resulting from intensive breeding and selection work, and are therefore well adapted to the local ecological conditions. The HA sorghums, by contrast, are new introductions and it is likely that by breeding and selection they will relatively easily produce lines of superior productivity. Thirdly, it may well be that the HA sorghums, of which very little is known about their optimal crop husbandry, would have benefited from different plant spacings. The latter two aspects are examined in the next paragraph.

\section{The scope for obtaining yield increases}

A problem when commencing a screening trial of this nature, is that of identifying the optimal management practice for each crop. Thus although the planting densities chosen were within the accepted range of good husbandry practices for each species, it is possible that individual groups would have benefited by the use of higher or lower populations. To investigate this subject further, and also to examine the prospects for improvement by selection and breeding, the original data for Table 3 have been subjected to correlation analysis.

In view of the importance attached to lodging as a factor which reduces the net yield of a forage crop when it is made into silage, particular attention has been paid to the importance of stem length and tiller population as they affect forage yield (Table 4).

The question of whether the correlation between two variables is statistically significant, is different from that of how much the variability of one character explains the variation in another. This is clearly demonstrated if one compares the combined effects of stem length and tiller population on the total yield of sunflower and HA sorghum (Table 4). In both cases the correlation is highly significant $(\mathrm{P}<0.001)$ but the explanatory value $(\mathrm{D} \%)$ varies from over $90 \%$ for sunflower to only just one third for sorghum.

Stem length can be varied according to the choice of cultivar planted, and tiller population is a function both of cultivar and seeding rate; guide as to the relative importance of these two factors can be obtained from a study of the standard partial correlation coefficients shown in the table. For example, the coefficients for stem length and tiller population for HA sorghums are 0.51 and 0.24 , respectively. This implies that the statistical chance of obtaining a higher yield is equal whether one 
NEW FORAGE CROPS FOR INCREASING BEEF PRODUCTION IN KENYA

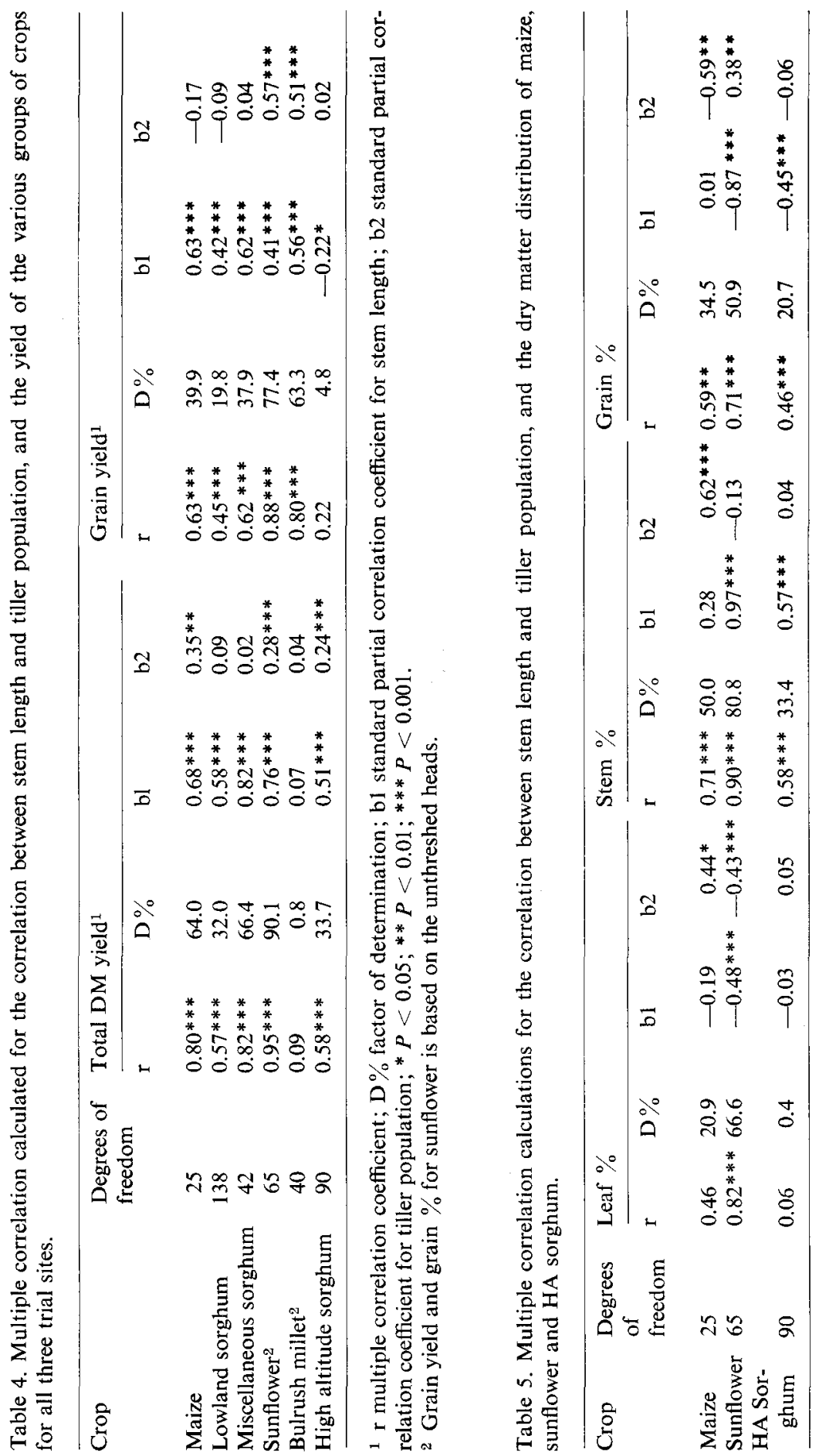

Neth. J. agric. Sci. 25 (1977) 
chooses a $10 \%$ taller variety or a $21 \%$ higher tiller population.

The problem posed by these findings hinges around the fact that stem length, and to a lesser extent tiller population, are also positively correlated with the susceptibility to lodging. From the point of view of mechanical forage harvesting shorter crops than the presently used maize cultivars would be advantageous. It is, therefore, of particular importance to know about the possibilities of achieving higher yields without increasing stem length or population. This is indicated by the differences not accounted for by the multiple regression (i.e. $9.9 \%$ for sunflower, $36.0 \%$ for maize and $66.3 \%$ for sorghum). The disadvantage of sunflower can further be seen from a simple linear regression calculation which revealed that $85.2 \%$ of total plant yield differences can significantly $(\mathrm{P}<0.001)$ be explained by plant length differences only. The fact that eight different sunflower cultivars, varying in average height from 94 to $385 \mathrm{~cm}$, were planted at three ecologically different trial sites and that such a large proportion of the yield variance was correlated with plant length differences, indicates that there is little scope left for exploring the variability towards finding high DM yielding varieties of reduced length and thus reducing lodging susceptibility.

Grain yield is also positively correlated with stem length and tiller population except for HA sorghums. This implies that whereas for maize tallness is an apparent necessity for high grain yields, there is a small but significant indication that shorter crops produce higher grain yields for HA sorghum.

The implication of this correlation analysis is that there appears to be scope for choosing HA sorghum lines with high yields of DM and grain within the range of variability used. For the other group of crops the scope for such a choice is far more limited. Presumably, further improvement by selection and breeding can be achieved more easily with the HA sorghums as parent material than with the maize or sunflower lines which were studied. It should be noted, however, that the analysis is valid only over the range of the relatively narrow genetic base available for this study.

The analysis in Table 5 shows the correlation between stem length and population and the plant components. It has been assumed that leaf $\%$ and grain $\%$ will have a positive influence on the nutritive value of the forage. Once again it appears that the situation is most favourable in the HA sorghums group, since a reduction in stem length is accompanied by a lower stem $\%$ and increased grain $\%$. If shorter varieties are then planted more densely, there will be no noticeable effect on DM distribution, within the range considered. For sunflower the combined effect of plant size reduction and increased population has a similar effect on DM distribution to HA sorghums. Maize, by contrast, does not have a changed plant composition where shortened, but when planted at higher population its stem proportion and leaf proportion is increased at the expense of grain formation.

\section{Conclusions}

In plant introduction work, the results of a single year are an insufficient base for definite conclusions. However, it is clear from the data presented that cold-tolerant 
sorghums look to be the most promising of the groups studied and, therefore, warrant further investigations. Some of these sorghums produced yields equal to, or more than maize. An important factor in favour of sorghum proved to be its lodging resistance. This ensures that the nett yield under commercial systems of cultivation will be close to the yields measured in these trials. Maize, by contrast, will, under such large-scale cultivation systems, produce a lower yield because of its harvesting losses. The observation on lodging combined with the correlation calculations presented above suggest that sorghum yields can be improved further by planting higher populations, whereas maize yields will be reduced owing to the necessity of lower plant populations. It is further argued that the scope for obtaining yield increases by selection and breeding is greater for sorghum than for maize. The HA sorghum cultivars ' $\mathrm{E} 6518$ ' and ' $E$ 1429' for total DM yield, and 'E 1291' for grain yield, appeared as the most promising lines. A clear disadvantage of the HA sorghums proved to be their comparatively slow initial growth, which increased the problems with weed control.

As a result of the above analysis, work was put in hand to enable a further evaluation of the place of HA sorghums in feedlot farming, and to investigate how their productivity can be improved upon. Specific areas of field experimentation include the following.

1. Given the difference in lodging susceptability between maize and sorghum and the mechanical harvesting losses resulting from it, studies were undertaken to establish the relation between experimental plot yields and yields obtained in largescale mechanical harvesting systems.

2. Studying the effect of different methods of weed control on sorghum production.

3. Investigating the influence of fertilizer application on yield and quality of sorghum grown under different rainfall regimes.

4. Establishing the growth curves of sorghum as affected by environment and plant population in relation to those of maize.

5. Examining the feeding value of sorghum as affected by agronomic practices, grain content and time of harvest in relation to maize.

6. Studying the yield stability of HA sorghum under different ecological conditions.

\section{Acknowledgments}

This paper is the first of a series of studies which were undertaken as a part of the programme of work of the UNDP/FAO/Kenya Beef Industry Development Project.

I would like to express my sincere gratitude to my colleagues for their interest and their assistance. In particular I am grateful to Dr M. J. Creek, the Project Manager, for his encouragement and his continuing interest.

My thanks are due to the Director of Research of the Kenya Ministry of Agriculture, to the Director of the Plant Production and Protection Division of the FAO and to the UNDP for their permission to publish this paper. 


\section{References}

Anonymous, 1970a. Survey of Kenya. National Atlas of Kenya. Kenya Government, Nairobi. Anonymous, 1973. Development plan 1974-1978, Republic of Kenya. Government Printer, Nairobi.

Anonymous, 1974. Economic review of Kenya agriculture. Econ. Planning 6 (4). Ministry of Agriculture, Kenya.

Anonymous, 1975. Statistical abstracts. Central Bureau of Statistics, Ministry of Finance and Planning, Nairobi.

Bengtsson, A., 1958. Silage plants for sandy soils. Meddn St. JordbrFörs. 93: 125.

Boonman, J. G., 1969. Sorghum and Sudan grass hybrids for dry season grazing. Kenya Farmer. July 1969.

Brown, L. H., 1963. The development of the semi-arid areas in Kenya. Ministry of Agriculture, Nairobi.

Cotte, A., 1957. Le tournesol-fourrage. Annls Amél. Pl., Paris 7 (3): 349-357.

Creek, M. J., 1971. A Zebu feedlot in Kenya. Span 14 (3): 166-169.

Creek, M. J., 1973. Rations used and results from feeding trials. Actes du Colloque 'L'embouche intensive des Bovins en Pays Tropicaux' (Dakar) EMVT, Paris.

Creek, M. J., D. M. Redfern \& H. A. Squire, 1974. Intensive cattle feeding in Kenya using high levels of molasses. World Rev. Anim. Prod. 10 (4): 58-68.

Creek, M. J., H. A. Squire \& J. Mulder, 1976. Fresh sugarcane as a substitute for maize silage in beef cattle rations. World Rev. Anim. Prod. 12 (3): 35-42.

Daly, L. A., 1974. Final report of Kenya Meat Commission abattoir/cold storage study. U.S. Agency for International Development, Project No 615-12-130-160, Washington D.C.

Doggett, H., 1970a. Sorghum. Longmans, Green \& Co., London.

Edmunds, L. K., M. C. Futrell \& R. A. Frederiksen, 1970. Sorghum diseases. In: J. S. Wall \& W. M. Ross (Ed.), Sorghum production and utilisation. Avi Publ. Comp., Westport, Conn.

Eijnatten, C. L. M. van, 1971. A growth analysis in sunflower cv. 'Giant White' at Kabete. Tech. Comm. Dep. Crop Prod. Univ. Nairobi No 2.

Eijnatten, C. L. M. van, 1973. Dry matter and its composition in the sunflower plant cv. 'Grey Stripe' from onset of flowering. Tech. Comm. Dep. Crop Prod. Univ. Nairobi No 8.

Glover, J., 1959. The apparent behaviour of maize and sorghum stomata during and after the drought. J. agric. Sci. 53 (3): 412-416.

Hagsand, E., 1956. Trials with annual fodder crops. Nord. JordbrFörsk. 38 (3-4): 352-356.

Henning, P. D., 1949. Silage crops. Farming in South Africa (June 1949) 291-297.

Martin, J. H., 1930. The comparative drought resistance of sorghums and corn. J. Am. Soc. Agron. 22 (12): 993-1003.

Miller, T. B., A. Blairrains \& R. J. Thorpe, 1963. The nutritive value and agronomic aspects of some fodders in Northern Nigeria. 2. Silages. J. Br. Grassld Soc. 18 (3): 223-229.

Putt, E. D., 1963. Sunflowers. Field Crop Abstr. 16 (1): 1-6.

Quinby, J. R., N. W. Kramer, J. C. Stephens, K. A. Lahr \& R. E. Karpar, 1958. Grain sorghum production in Texas. Bull. Texas agric. Exp. Stn 912.

Ross, W. M. \& O. J. Webster, 1960. Culture and utilisation of grain sorghum. Agric. Inf. Bull. 218: 1-18. Agricultural Research Service, U.S. Dept. of Agriculture, Washington, D.C.

Schuster, W., 1954. Die Sonnenblume, eine ideale Futterpflanze. Dt. landw. Presse 77 (10): 137-138.

Sivokonev, A. W., 1959. The effect of sowing date on sunflower yield. Zemledelie (Agriculture USSR) 7 (2): 53-56.

Swynnerton, R. J. M., 1953. A plan to intensify the development of African agriculture in Kenya. Government Printer, Nairobi.

Taylor, D. R. F., 1974. Spatial aspects of Kenya's rural development strategy. In: B. S. Hoyles (Ed.), Spatial aspects of development. John Wiley, London.

Warren Wilson, J., 1966. High net assimilation rates of sunflower plants in an arid climate. Ann. Bot. 30 (120): 745-7г1. 